\title{
The benefits of teleworking
}

Moderate mobility: reducing stress and greenhouse gas emissions

Patrice Tissandier and Sophie Mariani-Rousset

\section{(2) OpenEdition \\ Journals}

Electronic version

URL: http://journals.openedition.org/rfst/831

DOI: $10.4000 /$ rfst.831

ISSN: 2492-3672

\section{Publisher}

Espaces et SOciétés (UMR 6590)

\section{Electronic reference}

Patrice Tissandier and Sophie Mariani-Rousset, "The benefits of teleworking", Revue francophone sur la santé et les territoires [Online], Mobility, Transports and Health, Online since 27 May 2019, connection on 06 April 2021. URL: http://journals.openedition.org/rfst/831 ; DOI: https://doi.org/10.4000/rfst.831

This text was automatically generated on 6 April 2021.

\section{(c) (i) (9)}

La Revue francophone sur la santé et les territoires est mise à disposition selon les termes de la Licence Creative Commons Attribution - Pas d'Utilisation Commerciale - Partage dans les Mêmes Conditions 4.0 International. 


\section{The benefits of teleworking}

Moderate mobility: reducing stress and greenhouse gas emissions

Patrice Tissandier and Sophie Mariani-Rousset

1 Telework allows, on a voluntary basis, a professional activity outside the main workplace, thanks to information and communication technologies.

2 As a form of distance work organization, teleworking examines society in its environmental, economic and human dimensions (assets and constraints). The EFFETS' project, conducted in France, aims to measure and analyze the impact of distance work - considered here as the possibility for an individual to work from home or from a third place, other than his or her usual place of work, one or twice a week. To do this, two surveys were performed.

3 Initially, several employees from two different companies participated in an experiment to work at home on certain days for several months. Some of them were "à la carte", that is to say they had a package of ten days they placed as they wanted according to professional requirements, management and colleagues. Others were "regular", that is, they did one to two days of work each week at home. This participation was made on the basis of employee volunteerism with the agreement of the hierarchy. The testers answered an online questionnaire each week and each month; and at the end of the experiment, they participate in an interview to analyze issues about teleworking, especially effects on physical and mental health.

4 Two objectives were allocated to this 6-month experimentation phase with 18 people employed in 3 organizations ( 2 private companies, 1 public administration): first, to better understand the feelings of those involved (through interviews) and second, to estimate the impact of change in daily mobility on travel and the reduction of GHG emission levels through a simulation via the MobiSim platform, within the ThéMA laboratory. MobiSim is a Land Use and Transport Integrated (LUTI) model, quite similar to PROPOLIS, URBANSIM or MIRO. Several "plausible" scenarios were thus established, and two scenarios, aimed at measuring the impact of a strong public policy in favor of telework, were tested. A first "high" scenario concerns the possibility of teleworking for $50 \%$ of executives, $30 \%$ of intermediate professions and $20 \%$ of employees at 2 days per week and $10 \%$ of workers once a week in third places (type 1,2 and 3). The second, 
said "very high" applies to $75 \%$ of executives, of which $25 \%$ once a week and $50 \%$ twice a week; $60 \%$ of the intermediate professions, with $20 \%$ once a week and $40 \%$ twice a week; $45 \%$ of employees, $15 \%$ once a week and $30 \%$ twice a week; and $20 \%$ of workers, $10 \%$ to once a week, $10 \%$ to twice. In order to obtain a standard, a simulated initial situation, without teleworking, is carried out on both study areas.

5 Simulations and experiments were carried out in the territories of Lille Métropole and the "Communauté d'Agglomération du Grand Besançon"; the investigation took place in Lille. If we note a general increase in mobility, it is however through a change in modes of travel - with reduction of the car use (and public transport) in favor of walking.

6 The reduced drop in mobility thanks to teleworking shows that, overall, the experiment is successful - both in terms of the effects on pollution and the emission of greenhouse gas and on the physical and moral health of the respondents: positive effects on stress are significant and the quality of life is improved (Figure).

Figure: Positive contributions of teleworking on health

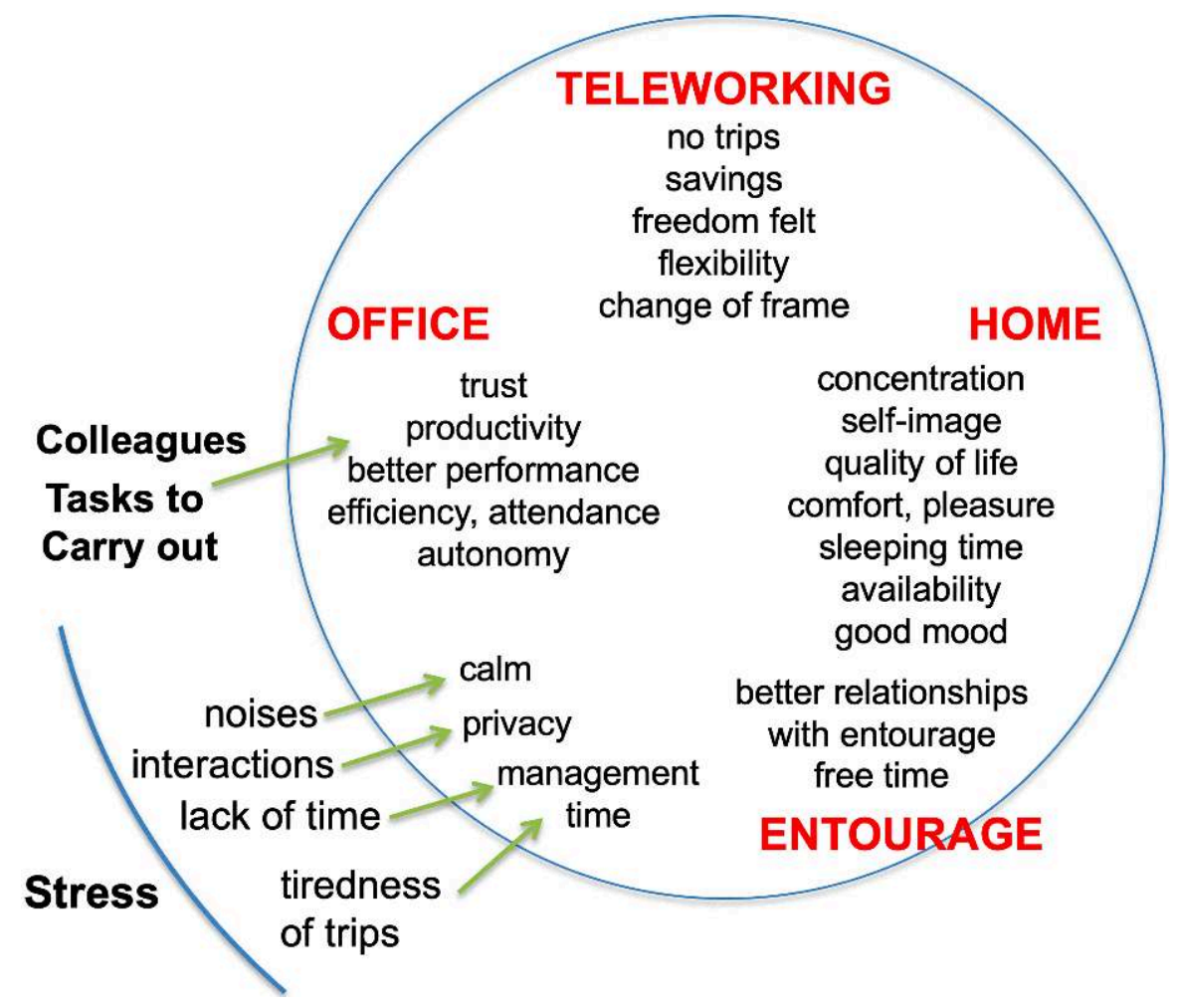

INDEX

Keywords: profesionals practices, mobility, teleworking, stress, greenhouse gas emissions 


\section{AUTHORS}

\section{PATRICE TISSANDIER}

Maître de conférences en géographie Université de Franche-Comté, France, laboratoire ThéMA

SOPHIE MARIANI-ROUSSET

Maître de conférences en psychologie Université de Franche-Comté, France, laboratoire ELLIADD/CCM 